\title{
The Council of the Marches in the Seventeenth Century
}

$\mathrm{O}^{\mathrm{F}}$ F late years some additional material has become available for the study of the Council of the Marches in the seventeenth century. The British Museum has acquired from Mr. W. D. Dovaston of West Felton, co. Salop, a Register of the Council of Wales and the Marches, 1586-1644 (Egerton MS. 2882), which was once the property of Mr. Moor (More), of Linley House, Shropshire, a descendant of Colonel Samuel More, a leading Shropshire Parliamentarian. Further, the National Library of Wales at Aberystwyth has acquired a folio volume entitled Welsh Patents, which was formerly in the possession of Austin Cooper, an Irish antiquary, and was later included in the Phillipps collection (no. 6462). Reference was made to both these volumes in the evidence recently given before the Royal Commission on Public Records ; ${ }^{1}$ it was not, however, stated that a very full summary of the register now in the British Museum was published in 1882 in the Thirteenth Report of the Historical Manuscripts Commission, app. iv, pp. 247-82. Moreover, the letters preserved at the end of the register (fo. 282-3) show that it was used by Clive for his 'Documents connected with the History of Ludlow'. A third notable manuscript of which, so far as I am aware, no use has hitherto been made, is now in the Cardiff Public Library (MS. $256=$ Phillipps 17118). It contains summaries of various suits brought before the Court of the Council of the Marches in the reign of James I. By the aid of these three documents it is now possible to trace with some fullness the working of the court in the seventeenth century.

When so few contemporary records of the Council have survived, it is regrettable to find that a large number of entries are common both to the British Museum register and the Aberystwyth volume of Welsh Patents. The numbering of the various entries corresponds, but the British Museum register cortsins several that are not in the other volume; these, however, are either unimportant or (as in the case of the instructions to the various lords president) occur elsewhere. From the two volumes

1 Report, iii. $75,126 b$. 
a good deal of information can be gathered as to the amount of business done by the court in the early seventeenth century. Two of the councillors certified (in 1617 probably) that during the Trinity Term

wee heard there [ $s c$. at Ludlow] above 260 Causes sett down for Hearing concerning poor men at a small Charge unto them and near their own Country, besides as many Rules and Motions for many misdemeanors and offences concerning his Majesty.

Little information is given as to the details of the cases before the court, but there are several references to the miscellaneous work it was expected to perform. For example, in 1620 the councillors were directed by the lord president, the earl of Northampton, to call in any current copies of a letter which 'Mr. Alured hath very unadvisedly written against the match with Spain'. About the same time the councillors were to see that

the Lottery shall be presently removed from Bewdley and that it continue no longer within the Marches of Wales to the Impoverishing of his [sc. the king's] subjects there, unless it bee in some great and wealthy townes and Cittyes, with speciall care of the Governors that the poor be not suffered to venture, or els to be absolutely dismist and forbidden, according as you in your Discretion and wisdome shall think fitt.

The lord president and Council were directed by the privy council to aid Hugh Middleton, the farmer of the royal mines in Cardigan, to suppress disorders in alehouses, and to compose differences that might arise in the course of his work Again, they were to do their best to arrest Sir Giles Montpesson (Mompesson) in 1621, to secure the keeping of the peace at an election at Carnarvon, and to prevent the spoiling of his majesty's woods at Bewdley. In 1622 they wrote to the bailiffs of Denbigh respecting the election of an alderman, and in 1623 the lord president was responsible for the delivery of writs of summons for parliament, directed to all the shires of Wales.

Very noteworthy is the anxiety of the lord president and Council to maintain the authority of the Council, imperilled by the desire of the four border counties to escape from its jurisdiction. The register contains a few direct references to the Fareley case, which raised the question of the extent of the Council's jurisdiction and went on down to $1608 .^{2}$ The lord president, Lord Eure, and the other members of the Council did their best to uphold their authority; so did their subordinates, such as Robert Medcalf, Lord Eure's servant, who was made attorney of the court in 1612 for his zeal 'concerning hi:

$=$ Egerton MIS. 2882, fo. 33 , no 33 ; fo 5.5, no. 42 ; fo. 57 , no. 44 . 
Lordshipp's particular business, as also in following and solliciting divers suits and matters of Oppositions and supposed Grievances against the Jurisdiction and Authority of this Honble Court'. A few years later, a man 'so strongly allyed in his country' as Sir John Wynne of Gwydir submitted himself at the council table in the presence of the lord president and five councillors. At times the anxiety of the Council to maintain its authority seems somewhat ridiculous, as in the case of Mr. Edward Lingen, who was long imprisoned in the porter's lodge at Ludlow for breach of several orders of the Council. At last he was found to be a lunatic, and the custody of his body, lands, and goods was committed by order of the court of wards and liveries to Sir John Scudamore. Lingen was to be conveyed to one of his own houses 'to be guided and attended for the speedy Recovery of his health, whereof there is great hope as is alleged '. Should this hope be realized, he was to be remitted to the lord president and Council 'to answer his contempts', and probably to have another experience of the porter's lodge.

In the seventeenth century the Council of the Marches was not only a bugbear to the inhabitants of the four border counties ; it could be used by a litigant as a means of embarrassing an adversary. We find that the opponents of Walter Vaughan (who was concerned in two cases that were to be heard in the Star Chamber) preferred several informations against him before the Council of the Marches, and planned that the Council's pursuivant should lie in wait for him at Gloucester. The pursuivant was just a night too late, and the plot failed ; Vaughan, however, petitioned the lord keeper that a writ of privilege or some protection for the next term might be granted him. The lord keeper accordingly wrote to Sir John Bridgman, chief justice of Chester, directing him to see that Vaughan was not disturbed in the prosecution of his suit. The registers contain some references to the issue of prohibitions from the common law courts at Westminster. The king, in a letter to the earl of Bridgewater, who was lord president from 1631 to 1642 , speaks of such prohibitions as defeating the end for which the president and Council in the principality of Wales and the Marches thereof were established, viz. 'for the more speedy administration of Justice and ease of our good people in those remote parts without drawing them to attendance here at Westminster to their exceeding great charge and trouble'. The lord president gave the very sensible advice to the Council, to be careful in the drawing up of bills, so that occasion might not be given for the issue of such prohibitions.

A point much insisted upon in the numerous instructions and orders to the Council was the careful keeping of the records. During the seventeenth century these exhortations seem to have 
borne fruit, for the registers often contain notes such as the following: 'The Originall in the Box with the King's Letters.' 'Originall in the white Box with the King's Letters.' Sundry orders were issued respecting the writing of bills and answers by attorneys and clerks ' without any Rasing, interlining, or blotting'. Original books or depositions were not to be delivered out of the office unless copies were taken of them. A book of assignment was to be kept for the entering of matters of court, and likewise a calendar of suits. In 1624 a peremptory order was issued that attorneys and clerks were to return informations, bills, and books within fourteen days after the end of term under penalty of being debarred from practice during the pleasure of the lord president and Council. Care was evidently taken in copying important documents into the register; occasionally a note is appended, 'Examinatur et Concordatur cum Originali'. By the time that the criminal jurisdiction of the court was abolished in 1641 there must have been a large accumulation of records; and by the reference to the records of the court in Lord Carbery's instructions, clause 8 (dated 9 September, 13 Car. $\Pi$ ), ${ }^{3}$ it would appear that they survived the Civil War.

Indications are not wanting that certain disorders had crept into the court in spite of the vigorous efforts for its reform in the reign of Elizabeth. The following warning was addressed by the queen to the earl of Pembroke, lord president, in 1590 :

it hath appeared that heretofore larger allowance hath bin made then was needfull to sundry of that Councill being but of mean estate coming thither sometimes more for their own and their Friends' Causes than for Ours Or the Administracion of Justice.

At frequent intervals orders were issued in restraint of sundry abuses; for instance, in 1609 any counsellor or attorney misreciting the cause in any material point was to pay $2 s$. $6 d$. for every default to the poor man's box. A later order restrained leading interrogatories; this was in the interest of the witnesses, many of them being 'simple men'.

The meeting-place of the Council in the seventeenth century was usually Ludlow, but Tickenhill and Bewdley were occasionally substituted. The registers furnish a few details about the Council mectings which somewhat relieve the monotonous recital of patents and orders. In the summer of 1631 several inhabitants of Shrewsbury and Wrexham died of the plague, and the Council ordered "that the personal appearance of all the inhabitants of the said towns be spared in this Court till further order be taken in that behalf '. The effort of the declining little court to maintain

- Phillipps US. 6162 ad fin. 
all the dignity it could muster may be seen in the following memorandum dated 21 May 1617 :

That this day in full Court, being the $1^{\mathrm{a}}$ day that this Lord President sat in Court in sight and presence of the whole Assembly there, . . . the said Lord President humbly Kneeling upon his Knees tooke the Oathes of Allegiance and Supremacy to his Majesty the same being to him ministred by the said Chief Justice.

Similarly Lord Eure desired the Council to 'give order that the officers and ministers of the court go out on Saturday to meet the Justice upon his first coming, which will bee on Saturday after dinner '.

The official records of the Council clearly show that its importance was declining in spite of vigorous efforts to support its authority. The volume (no. $235=$ Phillipps 14963) now in the Cardiff Public Library shows that it had excited odium enough for some unknown writer, evidently well acquainted with its procedur', to compile a statement of its misdeeds extending to several hundred quarto pages. The manuscript bears no date, but it is clear from internal evidence that the cases belong to the reign of James $I$. The curious and interesting attack on the Council is planned as follows. First the substance of each article of the instructions is stated, then the intention of each article taken in its literal sense, then come the "grievances of the Inhabitants of Wales and the marches of the same by resone of every of the said articles'; lastly comes the 'comon practise of the said Councell by coloure of every of the said articles to prove the aforesaid grievances'. The Council is roundly accused of oppression and injustice under colour of its instructions; a man can hardly do anything, such as raise his hand in his own defence, or defend another from being murdered or maimed, or bid his friends to a wedding dinner, or travel along the highway, \&c.,

but hee shalbe subiecte to be questioned wrongfully before the councell and fined to as much as hee is worth and more, all his lands and goods sequestred, seased uppon, sould and confiscated ... his wife and children to be turned a begginge, his body taken and imprisoned, and to have his owne bedclothes taken from hym and hyred to others to ly in and otherwise detayned from hym, and the prisoner forced eyther to ley [sic] uppon plankes . . . or to heyre unfyttinge and unholsome beds of the Jaylor at what rate the Jaylor will.

The composition of the Council is blamed as being the cause of much oppression :

the said greate nomber of Counsellors are but shaddowes and shelters for 4 or 5 that are resident to tyrannise and oppresse a great nomber of subiectes to theire greate gayne and benefytt and to the greate impouerishment and greefe of the Comonalty in those partes. 
Another grievance has to do with the meeting-place of the Council :

the towne of Ludlowe dyd in former tymes, before the Councell came thyther, depend uppon Clothinge and were welthy persones and well to live all; and now sythence the Councell came thyther they converted there [sic] Clothinge stores to ferme, heye giound, and pasture, and to furnish there [sic] houses with houshold stuffe to entertayne straengers in terme tyme and to provide fuell and to mayntayne servants to attend one there gesse [i. e. on their guests] and in former tymes before ytt was exacted ytt was the Chepest towne wythin the marches of Wales for all suy tors to resorte unto untyll that of late yeares the lo: presidents to drawe money to there [sic] purses would putt out a rumor that the Councell would remove to some other towne for half a yeare wheare they might have 30 or $40^{1}$ for coming thyther for 6 monethes (if my lady president or the Stewarde could not perswade the lo: president to the contrary), and hereby all the Innkeepers' pasture and provisions would stand ... wythout any utterance for $y t t$ to there [sic] greate damage and undoinge of many a mann: and heare uppon the hole towne most [sic] call a Counsell to make a some of money of 30 or 401 to present my lady therewyth or the stewarde, and then the councell would remayne there or els they would remove to other places.

The councillors are next accused of downright injustice in many cases and of receiving bribes. A summary of a lengthy suit is concluded with the significant remark :

Nota that Davyd ap Rees was a rich mann and brought $30 \mathrm{li}$ in his purse to the hearing of the said cause and sent home from Ludlowe for more money and the said Mredydd [sic] ap Rees was a poore man and had not soe much money to spare.

Other accusations against the Council were that it entertained vexatious suits brought under colour of suppressing the practice of comorthas or unlawful contributions, and that the article in the instructions intended to prevent the embezzling of books and records was at times perverted into a means of injustice. One very general charge was that the Council entertained trifling and frivolous suits, and the following case oi the parson and his parishioner certainly shows that it occasionally, at all events, disregarded the maxim ' de minimis non curat lex' :

uppon a reconinge for church dutyes one an Ester day there fell out an halfpeny due to the parsone [of Llanngynntor, perhaps Llangunnor, near Carmarthen] which one of the parishioners could not give hym because there wanted chaenge, and because the parsone would not lose or diminish the right of the church and the parishioner the Custome of the parish, the parsone and the parishioner concluded to cast crosse and pile for the od halfepeny that they could not chaenge, and for soe doinge they were both questioned before the Counsell of the Marches as a matter of greate misdemeanour. 
Some of the cases quoted throw noteworthy light on the relations between the Welsh and the English. A certain 'Katherin verch Harry Morgan ' learnt some Welsh rhymes and was accused, together with her father and mother, of slandering a certain Sara; the rhymes were not translated, so that the court could not judge whether they were libels and scandalous or not, and yet the girl, who was under sixteen years of age, was committed to the porter's lodge till she should pay 100 marks fine and 20 nobles costs: furthermore she was sentenced to stand on a scaffold with paper and superscription about her head with 'cappitall letters' at the then next great sessions for Cardiganshire, to acknowledge her offences before the whole audience in the shirehall, and then to be brought to the cucking-stool, and there cucked the first day of the assizes and again on the Thursday next following. The irritation caused by the enclosure of waste is shown in the following case. The township of Wylley had a piece of waste land held in common by the inhabitants: Sir Thomas Cornewall claimed it, got an order from the Council of the Marches for the possession of it, and leased it after some time to John Richards and his wife. One John Powell, ' a yonge youth of the said towne', happened to cut with his knife in the greensward on the highway the 'portraiture' of a gallows with a man leaning against the ladder, also certain verses and the letters J. R. Powell was summoned by Richards before the Council, and when asked whether he meant John Richards by the $J$. and R., he answered with cautious indirectness that ' hee dyd not meane hym more than another man'. The president would not be put off with this evasive reply, and asked if he meant the king (Jacobus Rex) or John Richards; one of the two he must have meant. The luckless youth, being thus brought within suspicion of treason, hastily replied that he did mean John Richards, and was fined $£ 20$ and costs.

The unknown writer describes with burning indignation the misdeeds of the porter and the discomforts of the porter's lodge. 'The following complicated series of misfortunes that befell one Webb deserves mention.

The said Webb beinge one Good Friday drawinge and fishinge of a poole of fish was arested in the poole (by virtue of a warrant) and taken away before hee had taken upp his fish after that the poole was drawen drey, and brought to Ludlowe castell one Ester day; and when hee. came to Ludlowe the porter would not receave hym, whearefore the Constable toke hym home wyth hym and before the said Webb came then home all his Carpes, Flies, and fish were stolen and taken away by Crowes and pies and destroyed in the mudd, some of the Carpes beinge worth $18^{\mathrm{d}}$ a peece and some of the yeales $[s i c]$ being worth $2^{s}$ a peece, and there was then lost and destroyed aboue $5^{1}$ worth of fish. 
Moreover, because Webb was not in his parish church on Easter Day to receive the communion, he was called to the bishop's court and enjoined to do penance. Another case of hardship was that of one Perryn, a Greenwich man, who came to Herefordshire on the king's service and was apprehended on a binding process. For want of sureties he was committed to Hereford gaol for nine weeks, was then brought before the Council and kept a prisoner in the porter's lodge for a fortnight. To maintain himself he was forced to sell his horse, besides spending all his ready money, and 'the matter laid to his charge most unjust'. The irritation against the Council is explicable when we read of the exactions of the porter in meat and drink and lodging: he would put 2,3 , or 4 persons in every bed, and sometimes $5,6,7$, or 8 persons, ' as the pallat [sic] is able to cover, and putteth what price hee thinketh good uppon there [sic] lodginge'. This series of complaints concludes with a list of 'greate annoyances to the prisoners' :

that the porter keepeth his Coales and other Baggages over the prisoners' heads in a garrett full of holes in the floore, the dust thereof fallinge one [sic] the prisoners in there [sic] bedds; and as they walke when they are upp and as they sytt at meate the porter's servants runninge thyther at all times of the day and sturringe those Coales and Baggages.

Also

that the porter placed his hawkes to mewe in the best rowmes of the prisone and turned gentry to the Comon Jayle: the said hawkes doinge greate annoyance in breedinge flies to fill the prisone therewyth.

A point of much interest in this lengthy indictment is that the names given are very largely Welsh; it is also definitely stated 'that noe man that was borne in Wales or ever had any beinge or dwellinge there cannot be free from the oppression of that Courte' (fo. 522). This goes to prove that the Council was growing unpopular in Wales as well as in the border counties. It should be remembered that after the Revolution the Council was presented for a grievance by most of the grand juries of the several counties of Wales, and that the members for Wales were charged by their constituents to represent it as a grievance in parliament. ${ }^{4}$

In addition to the foregoing manuscripts bearing on the history of the Council of the Marches a few of less importance may be mentioned, such as the volume in the National Library of Wales (Peniarth MS. 408), containing transcripts (all of which

- See the broadside, The Case of Their Majesties' Subjects in the Principality of Wales in Respect of the Court held before the President and Council in the Mfarches of Wales with their Grievances and Reasons for taking atcay the said Court, Cardiff Publio Library, MS. 373 (Phillipps 21183). 
occur elsewhere) dealing with the Four Counties case, Doddridge's Discourse of the Ancient and Modern Estate of the Principalities of Wales, extracts from Patent Rolls, lists of lords president, and so forth. George Owen's curious volume, the Taylor's Cussion (now in the Cardiff Public Library), contains: (i) a long petition (pt. i, fo. 20-3) to the Council on behalf of the inhabitants of Pembrokeshire touching divers abuses of stealing, marking, and killing of sheep ; (ii) a proclamation (pt. i, fo. 94-5) by the lord president and Council for the reform of sundry disorders within the limits of their commission, dated 1594; (iii) letters to two lords president and sundry lists (pt. ii, fo. 14 and $7-20$ ).

The material that can now be consulted at Aberystwyth and Cardiff only serves to deepen the impression gained from other sources that in the seventeenth century the Council of the Marches had outlived its usefulness, and that its survival was felt burdensome in districts where in former days it had conferred undoubted benefits.

Carolive A. J. Skeel. 